\title{
A Novel Entry to the Taxane Structural Unit**
}

By Harribert Neh, Siegfried Blechert*, Wolfgang Schnick, and Martin Jansen

Taxanes, such as, e.g., taxinin B 1 or taxol 2, are unusual hydroxylated diterpenes which occur in plants of the family Taxaceae, to which the yew tree (Taxus baccata L.) belongs ${ }^{[1]}$. The antileukemic and antitumoral activities of some taxanes ${ }^{[1]}$ and the problems encountered in the synthesis of the unusual tricyclic carbon skeleton 3 have aroused increasing interest in recent years ${ }^{[3]}$. According to in vitro experiments ${ }^{[4]}$, less substituted taxane derivatives could also be biologically active. For this reason it appeared to us that the synthesis of a tricyclic taxane skeleton with functional groups in ring $A$ and ring $B$ which should be readily convertible into hydroxy groups might prove rewarding. We report here on a stereoselective route to the tricycle 4 .

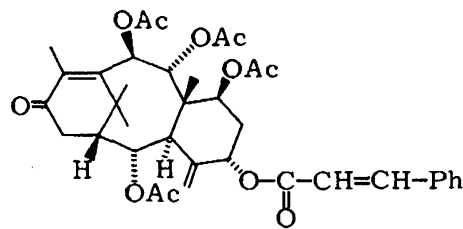

1

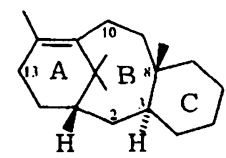

3

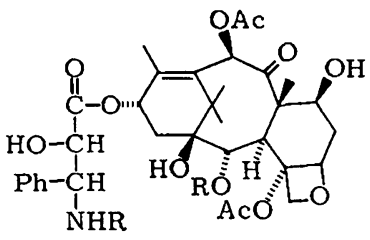

2, $\mathrm{R}=\mathrm{COP} h$

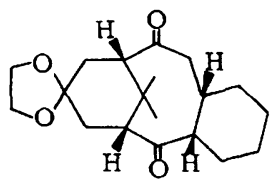

4

[*] Priv.-Doz. Dr. S. Blechert, Dipl.-Chem. H. Neh Institut für Organische Chemie der Universităt Schneiderberg 1 B, D-3000 Hannover 1 (FRG) Dipl.-Chem. W. Schnick [ ${ }^{+}$, Prof. Dr. M. Jansen $\left[^{+}\right]$ Institut für Anorganische Chemie der Universität Hannover (FRG)

$\left[{ }^{+}\right]$X-Ray structure analysis.

[**] This work was supported by the Deutsche Forschungsgemeinschaft and the Fonds der Chemischen Industrie. We thank Dr. V. Wray, Gesellschaft für Biotechnologische Forschung (GBF), Braunschweig-Stöckheim for recording the $400-\mathrm{MHz}$ 'H-NMR spectra. 
A problem in the synthesis of the taxane framework is the formation of the eight-membered ring. This has previously been achieved by way of intramolecular DielsAlder reactions, but this approach involved an aromatic ring $\mathrm{C}^{[5]}$ or simply dispensed of the bulky geminal dimethyl group ${ }^{[6]}$. For preparation of the central ring, we used the de Mayo reaction ${ }^{[7.8]}$. The key step of our reaction sequence $5 \rightarrow 4$ (Scheme 1) is the stereoselective $[2+2]-$ photocycloaddition of cyclohexenes to the bicycle 9 , since in this way the configuration at $\mathrm{C}-8$ of the taxane framework is fixed. A C-8- $\alpha$-ring coupling should be possible by a $\beta$ exo attack of the cyclohexene. As directing substituent we chose a ketal, which we expected would, according to model considerations, favor the formation of a $\beta$-adduct.

9a, $\mathrm{R}=\mathrm{Ac}$

$9 \mathrm{~b}, \mathrm{R}=\mathrm{CO}_{2} \mathrm{CH}_{2} \mathrm{Ph}$

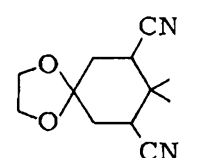

6

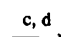

5

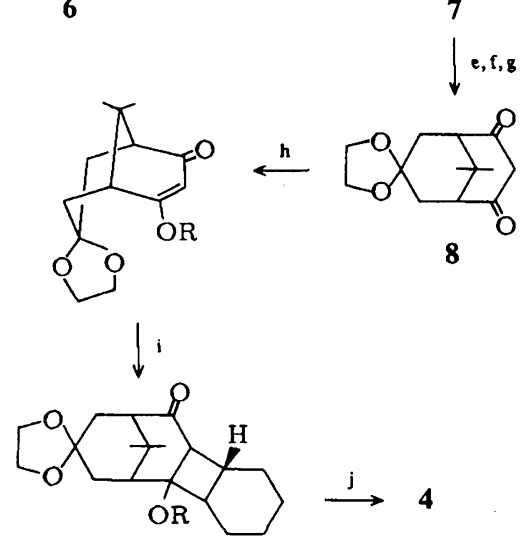

Scheme 1. a) $\mathrm{KCN}, \mathrm{NH}_{4} \mathrm{Cl}$, (DMF) $/ \mathrm{H}_{2} \mathrm{O}, 68 \%$ yield; b) $\mathrm{HOCH}_{2} \mathrm{CH}_{2} \mathrm{OH}$, ptoluenesulfonic acid, benzene, $83 \%$ yield; c) $\mathrm{KOH}, \mathrm{H}_{2} \mathrm{O}_{2} / \mathrm{H}_{2} \mathrm{O}, 3 \mathrm{~d}$ reflux, yield $88 \%$; d) dicyclohexylcarbodiimide, $\mathrm{CH}_{2} \mathrm{Cl}_{2}, 91 \%$ yield; e) MeLi, $-60^{\circ} \mathrm{C}, 55 \%$ yield; f) $\mathrm{CH}_{2} \mathrm{~N}_{2}, 95 \%$ yield; $\mathrm{g}$ ) $\mathrm{KH}$, xylene, reflux, $85 \%$ yield; h) $\mathrm{Ac}_{2} \mathrm{O} / \mathrm{NaOAc}, 96 \%$ yield or $\mathrm{ClCO}_{2} \mathrm{CH}_{2} \mathrm{Ph}, \mathrm{CH}_{2} \mathrm{Cl}_{2}$, aq. $\mathrm{NaHCO}_{3}, 86 \%$ yield; i) cyclohexene $/ \mathrm{CH}_{2} \mathrm{Cl}_{2}$, hv, $-78^{\circ} \mathrm{C}, 10 \mathrm{a}: 56 \%$ yield $+15 \%$ educt, $10 \mathrm{~b}: 65 \%$ yield $+30 \%$ educt; j) $0.5 \mathrm{~N} \mathrm{KOH} / \mathrm{EtOH}, 15 \mathrm{~h}, 56 \%$ yield.

Our strategy for the synthesis of the 1,3-diketone 8 enabled us to investigate intramolecular photocycloadditions also, since substituted 1,3-diketones can be synthesized from the anhydride 7 by reactions with alkyllithium compounds other than MeLi. Irradiation of the enol acetate 9a (500 W Hg high-pressure lamp (Pyrex filter), $4 \mathrm{~h}$,

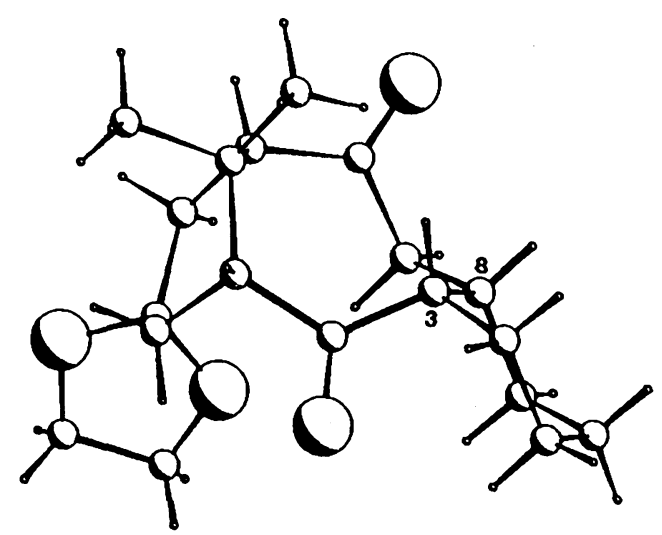

$-78^{\circ} \mathrm{C}$ ) in a $4: 1$ mixture of dichloromethane/cyclohexene led to $10 \mathrm{a}$, which, however, was less suited for the ring-opening, since elimination readily takes place with formation of cyclobutene. The benzyl carbonate $10 \mathrm{~b}$, which is obtainable in $65 \%$ yield (30\% recovered educt) from $9 \mathrm{~b}$ after chromatography can, on the other hand, be converted quantitatively by hydrogenolysis $\left(\mathrm{H}_{2}, \mathrm{Pd} / \mathrm{C}\right)$ into the alcohol 10c. The very slow retroaldol cleavage leading to formation of 4 ( $15 \mathrm{~h}, 0.5 \mathrm{~N}$ ethanolic $\mathrm{KOH}$ solution) is remarkable. After chromatography on silica gel, during which larger losses occur, the diketone 4 is obtained in $56 \%$ yield (m.p. $129-130^{\circ} \mathrm{C}$, crystallization from petroleum ether). The configuration at C-3 and C-8 could not be determined unequivocally on the basis of the NMR data $^{[9]}$ in the case of the strongly strained tricycle 4 ; however, this could only be established by X-ray structure analysis $^{[10]}$.

Received: July 13,1984 supplemented: September 4, 1984 [Z 924 IE] German version: Angew. Chem. 96 (1984) 903

CAS Registry numbers:

$4,92695-04-0 ; 5,1073-14-9 ; 6,92694-96-7 ; 7,92694-97-8 ; 8,92694-98-9 ; 9 \mathrm{a}$ 92694-99-0; 9b, 92695-00-6; 10a, 92695-01-7; 10b, 92695-02-8; 10c, 92695-039; $\mathrm{HOCH}_{2} \mathrm{CH}_{2} \mathrm{OH}, 107-21-1$; cyclohexene, 110-83-8.

[1] Review: R. W. Miller, J. Nat. Prod. 43 (1980) 425.

[2] M. C. Wani, M. L. Taylor, M. E. Wall, P. Coggon, A. T. McPhail, J. Am. Chem. Soc. 93 (1971) 2325.

[3] For recent studies on the synthesis see: a) B. M. Trost, H. Hiemstra, J. Am. Chem. Soc. 104 (1982) 886; b) K. Sakan, B. M. Craven, ibid. 105 (1983) 3732 ; c) Y. Ohtsuka, T. Oishi, Heterocycles 21 (1984) 371.

[4] V. Senilh, Dissertation, Université de Paris-Sud, Centre D'Orsay 1984.

[5] K. J. Shea, P. D. Davis, Angew. Chem. 95 (1983) 422; Angew. Chem. Int. Ed. Engl. 22 (1983) 419; Angew. Chem. Suppl. 1983. 564.

[6] P. A. Brown, P. R. Jenkins, J. Fawcett, D. R. Russell, J. Chem. Soc. Chem. Commun. 1984, 253.

[7] P. de Mayo, Acc. Chem. Res. 4 (1971) 41

[8] Synthetic applications: W. Oppolzer, Acc. Chem. Res. 15 (1982) 135; A. M. Birch, G. Pattenden, J. Chem. Soc. Perkin Trans. 1 1983, 1913.

[9] Supplementary ' $\mathrm{H}-\mathrm{NMR}$ data $\left(400 \mathrm{MHz}, \mathrm{CDCl}_{3}\right): \delta=3.8-4.2$ (ketal-H, $\mathrm{m}), 3.71\left(\mathrm{H}_{\alpha}-9, \mathrm{t}, J=12.2 \mathrm{~Hz}\right), 3.41(\mathrm{H}-3, \mathrm{t} \mathrm{d}, J=5.0$ and $1.2 \mathrm{~Hz}), 2.98$ $\left(\mathrm{H}_{\alpha}-14\right.$, ddd, $J=12.8,4.8$, and $\left.1.8 \mathrm{~Hz}\right), 2.48(\mathrm{H}-11, \mathrm{~d}(\mathrm{br}),. J=7.5 \mathrm{~Hz}$ ), $2.32\left(\mathrm{H}_{\mathrm{\beta}}-12\right.$, dd, $J=16.2$ and $\left.7.8 \mathrm{~Hz}\right), 2.05-2.13\left(\mathrm{H}_{\beta}-14, \mathrm{H}-1, \mathrm{H}-8, \mathrm{~m}\right)$, $2.01\left(\mathrm{H}_{\mathrm{\alpha}}-12\right.$, dd $(\mathrm{br}),. J=16$ and $\left.2 \mathrm{~Hz}\right), 1.97\left(\mathrm{H}_{\beta}-9\right.$, ddd, $J=12.4,6.0$, and $1.8 \mathrm{~Hz}), 1.75(1 \mathrm{H}, \mathrm{m}), 1.67(\mathrm{l} \mathrm{H}, \mathrm{m}), 1.1-1.5(6 \mathrm{H}, \mathrm{m}), 1.31(3 \mathrm{H}, \mathrm{s}), 1.45$ $(3 \mathrm{H}, \mathrm{s})$.

[10] $4=\mathrm{C}_{19} \mathrm{H}_{28} \mathrm{O}_{4}, M_{\mathrm{r}}=320.4 ; a=6.737, b=9.971, c=14.114 \dot{\mathrm{A}}, \alpha=69.37$, $\beta=83.98, \gamma=86.04, V=881.9 \dot{\mathrm{A}}^{3}, Z=2$, space group $\mathrm{P} \overline{\mathrm{I}}$. Data collection: Siemens AED2 diffractometer, $\mathrm{Mo}_{K_{\alpha}}$ radiation, graphite monochromator, scan width $1.2^{\circ}, \omega$-scan, 8080 measured reflections in the range $3.1^{\circ}<2 \theta<50.0^{\circ}, \quad 1723$ symmetry independent reflections with $F>3 \sigma(F)$, solution of structure by direct methods. Anisotropic refinement of all atoms other than hydrogen, hydrogen atoms isotropic, $R=0.0624$ for 208 free parameters, $R_{w}=0.0467, W=2.833 /\left[\sigma^{2}(F)\right]$. Further details of the crystal structure are available on request from the Fachinformationszentrum Energie Physik Mathematik, D-7514 Eggenstein-Leopoldshafen 2, on quoting the depository number CSD 51050 , the names of the authors, and the journal citation.

Fig. I. Structure of a molecule of 4 in the crystal (PLUTO-PLOT). 